\title{
Articles
}

\section{'The silence of the Sphinx': The delay in organising media coverage of World War II}

\section{AABSIRACII}

None of those New Zealand men who served as official war correspondents in World War II are alive today to tell their stories. It is left to the media historian to try and piece together their lives and actions, always regretting that research had not started sooner. Sadly there is more information available about World War I and the life and actions of Malcolm Ross, the country's first official war correspondent, than there is about New Zealand's World War II correspondents. Nevertheless, remembering the work of these journalists is important, so this is a first attempt at chronicling the circumstances surrounding the appointment of the first of the official correspondents, John Herbert Hall and Robin Templeton Miller, for the 1939-45 conflict. The story of the appointment of men to cover the war, whether as press correspondents, photographers, artists or broadcasters, is one of 'absurd delays' which were not resolved until nearly two years of the war had passed.

Keywords: journalism history, New Zealand, newspapers, public relations, war correspondence

\section{ALLISON OOSTERMAN \\ Auckland University of Technology}

7 HIS preliminary research focuses solely on the appointment of those official New Zealand correspondents sent expressly to cover the actions of the 2nd New Zealand Expeditionary Force (NZEF) troops and covers up until the establishment of the Public Relations Office in May 1941. Many reporters 
enlisted and were drafted in to perform journalistic functions such as editing troop newspapers or acting as public relations officers. Newspapers did have men in London, such as Alan Mitchell who acted for the consortium of The New Zealand Herald, Otago Daily Times, Press and Evening Post, but these will not be considered here; nor will the photographers, artists, broadcasters or film makers. What is also not going to be considered are the New Zealand men or women who were war correspondents writing for other nations' newspapers; for example, New Zealand-born journalists such as Osmar White, Lachie Macdonald and Kate Webb who wrote for Australian papers (Anderson \& Trembath, 2011; McDonald, 1998). In the light of these provisos, Malcolm Ross, as the first ever official war correspondent, will be highlighted before considering the appointment of the first of the World War II official war correspondents. This article will not provide a wider context to New Zealand's participation in the war and the role of newspapers in it. That will be included in later research, once all the official correspondents of the war have been identified.

\section{War correspondence prior to World War II}

The history of New Zealand's war correspondence up to 1918 has been covered in the thesis Malcolm Ross: From the peaks to the trenches (Oosterman, 2008) and in a previous article in Pacific Journalism Review (Oosterman, 2010) and was largely a refutation of the claim in The Oxford Companion to New Zealand Military History (McGibbon, 2000) that New Zealand had not established any 'strong tradition' of war correspondence. But clearly the New Zealand press did see the importance of covering war, both within New Zealand, during the land wars, and abroad, even when New Zealand troops were not involved and despite the great cost to the newspapers. A tradition was established - that of the soldier journalist, such as Claude Jewel who reported the South African War of 1899-1902, or that of the civilian journalist, such as Malcolm Ross, the official war correspondent of World War I, plucked from a freelance contract or a newsroom to cover armed conflict. A rarity was any newspaper independently sending their own journalists, although the New Zealand Herald and Auckland Star did send journalists Fred Carr Rollett and James Cowan respectively to cover the Samoan 'troubles' in 1899. One New Zealander, Rhodes Scholar Geoffrey Cox, covered the Spanish Civil War for the News Chronicle and the outbreak of war in Europe for the Daily Express (Purser, 2008), but did send back at least one despatch to New Zealand papers. 
He wrote a regular column, Behind the Cables, with John Mulgan, for the Auckland Star and in one described his three-week experience in Madrid during the Spanish Civil War (Cox, 1936). This was unusual.

It was more common for newspapers to band together to send a journalist to a war zone, but it was usually the cost that brought that journalist home, as happened with J. Elder Moultray and James Shand sent by a consortium of the Otago Daily Times, The Press and The New Zealand Herald to cover the South African War. When Ross became the country's first official war correspondent in 1915, a new concept in war correspondence was introduced; that of the state-appointed and paid war correspondent. World War II was to embed the concept of enlisted men acting as correspondents. In World War II 'almost all of them were recruited to the typewriter while shouldering arms in the field', as it was put by the New Zealand Journalists' Association (Association, nd).

\section{The appointment of World War I's official war correspondent}

When New Zealand declared war on Germany in 1914, New Zealand newspapers were immediately keen to ensure coverage of the war would be provided not just by overseas journalists but by their own, especially of the actions of the country's own forces. The Imperial War Office had given permission for one correspondent from each Dominion to be accredited. Quickest off the mark to put a name forward was the consortium of newspapers mentioned previously, dubbed the New Zealand Associated Press, which recommended Guy Scholefield, currently in its London office. When Parliament heard that on the recommendation of the High Commissioner in London, and agreement by Cabinet, but without further consultation, Scholefield's name had been forwarded as war correspondent to the War Office, the opposition party of Joseph Ward was incensed. He was also furious that Malcolm Ross, under the auspices of the NZAP, had embarked with the NZEF in the action to take German Samoa in August. Ward argued that the correspondent should be representative of all sections of the press. He also demanded that there should be no discrimination and any selection should not be made in favour of a particular political party (Expeditionary force: Press correspondents, 1914). The press should come together and vote on who should be that journalist, just as Australia had done when its press chose Charles Bean. Scholefield's name was withdrawn and in an attempt to break the impasse, another contender was proposed by the government, H. T. B. (Bertie) Drew, the recent editor

PACIFIC JOURNALISM REVIEW 20 (2) 2014189 
and proprietor of the Manawatu Daily Times who now worked on the Evening Post (Bell, 1915). That met with a flat rejection from the United Press Association. Political tensions ran high; neither political party could agree on who should be chosen, the newspapers were determined it would be someone all papers could accept. This contretemps had lasted nearly seven months and was covered extensively in the country's newspapers. It was eventually left to the government to propose a committee of two editors from each political persuasion to meet to consider the 46 candidates and choose the best two with the final decision being Cabinet's. Cabinet approved Malcolm Ross and in April he became the country's first official war correspondent, eight months after the declaration of war (War correspondent Mr Malcolm Ross appointed,1915). His was not a popular appointment and it was greeted by much derision from such papers as The Observer and Truth (Appointment of war correspondent, 1915; Our war correspondent, 1915). As a personal friend of the Prime Minister William Massey, Ross was seen as a government booster and as a freelancer, was not seen as having the necessary skills for such a position. Ross reached Gallipoli in June, hampered by the official requirement that he send his despatches by boat rather than cable, but given relative freedom by General Sir Ian Hamilton, the officer commanding the Mediterranean Expeditionary Force, to bivouac with the New Zealand troops rather than be confined to an offshore island like other correspondents. (Charles Bean was also given the same dispensation.)

Intense political rivalry between the government and the opposition was reflected in the press coverage of the whole appointment process. No punches were pulled in the debate which flourished in all the papers during the whole period. While most saw it as a certainty that prominent journalist Malcolm Ross would get the nod for the position as war correspondent there was considerable cynicism in many circles about his appointment. This did not fade and continued throughout the war. Despite many demands for his recall and despite requests that more correspondents be appointed, he remained the sole representative of the New Zealand press at Gallipoli and on the Western front for the duration of the war. Palestine, where New Zealand troops fought, was never covered.

\section{Press coverage of the appointment of the official World War II correspondents} There has been little research into the appointment of New Zealand's World War II correspondents. There is a briefmention in the Oxford Companion

190 PACIFIC JOURNALISM REVIEW 20(2) 2014 
(p. 579) and in The New Zealand Journalists' Association 1912-1962 (pp. 28-31) but it has been unusually difficult to find extensive material on the appointment process. There is enough however, to paint a preliminary picture. As with the outbreak of war in 1914, the first place a researcher into the 1939 conflict might turn to is the press coverage. This is where the New Zealand public in 1915 learned about the appointment of any correspondent. Papers Past, the digitised collection of 83 New Zealand newspapers from 1839 to 1945, provided extensive coverage for 1914. However, for the 1939-45 period, only two major daily newspapers, the Auckland Star and Evening Post at the time of publication are available, along with four smaller non-daily papers. The immediate impression, despite this, is of the paucity of coverage compared to 1914, of the need for correspondents to cover the war for New Zealanders. Where the papers in 1914-15 debated the issue widely in their pages, in 193940 there seemed to be virtually no debate, not even in the Star or Post. The first mention of a possible New Zealand war correspondent was in December 1939 when the Star reported that a phone conversation with the Minister of Defence, Fred Jones, had revealed the likelihood of a war correspondent being appointed by the government.

Mr Jones said that nothing had been done by Cabinet so far, but in the event of a decision to send a correspondent overseas all journalists would have an opportunity of applying for the position and setting out their qualifications for the appointment. (War correspondent-Expeditionary force, 1939)

Nothing further on the matter is reported by either of the dailies, but the Post does cover the appointment of the three official Australian correspondents, John Hetherington, Reg Glennie and Guy Harriott, but with no mention of any possible New Zealand war correspondents (War correspondents, 1940b). Finally, four months after war was declared, the Star broached the subject.

A matter of importance concerning New Zealand's war effort, and one which has been given practically no publicity, is the appointment of an official correspondent to report the doings of the New Zealand Expeditionary Force in the field. Journalists throughout the country are keenly interested, and it is believed that more than thirty of them have made application to the Minister of Defence for consideration. The government may, however, publicly invite applications for the post. In 
the war of 1914-18, the government appointed the late Mr. Malcolm Ross as New Zealand official war correspondent, with the honorary rank of captain. (War correspondent-Question of appointment, 1940)

Unlike the Post which gave little coverage to the question of New Zealand war correspondents, the Star now proceeded to provide some information, following up in February with the announcement that two journalists would be appointed by the government, one to travel with the 2nd Echelon ${ }^{1}$ and the other with the 3rd. (The 1st echelon had left for Egypt in January 1940 with no correspondent or photographer on board unlike the Australians who sent their three official correspondents and a cameraman with the first convoy of the 2nd Australian Imperial Force (AIF) in January.)

Many applications had been received, but no appointment had yet been made. The details of the conditions of appointment, such as whether honorary rank would be granted, had yet to be decided. In a previous statement Mr Jones said that every New Zealand journalist would have an opportunity of stating his qualifications for the position in the event of a war correspondent being appointed by the government. (News of the day, 1940)

It seems the Star was pushing the government to give more information about the country's war correspondents because in February again a Star reporter contacted the Minister of Defence to find out what progress has been made on any appointments. The Minister of Defence, Fred Jones, told the Star that because of the large number of applications already received by the government, the positions would not be advertised.

Mr Jones said a selection would be made of one correspondent as soon as possible, as it was intended to send him with the second echelon. A second correspondent would accompany the third echelon. The government was also considering the advisability of appointing an official photographer to go overseas with the forces. (War correspondents, 1940a)

All was silence again until April 6 when the Star reported an interview with the minister saying about 100 applications had been received for the position of official correspondent and were to be considered by a Cabinet committee established for that purpose. Jones reiterated that no appointments had been made and it had not yet been decided whether the government would engage 
two correspondents or one correspondent and a war historian (News of the day-War correspondent candidates, 1940). While the Post appeared less interested publically in the selection of press correspondents it was first to publish the government decision to appoint three men to the broadcasting unit to be attached to the 2nd NZEF in Egypt (Radio unit, 1940). Finally on April 15 both dailies published the announcement that John Herbert (Bert) Hall, the deputy publicity director, had been appointed official war correspondent. The lack of interest, debate or even speculation about whether the country would send correspondents to cover the actions of the 2nd NZEF is noticeably different from that which occurred in 1914-15. Why this was so, is hard to fathom. In 25 years what had occurred to occasion this dearth? That is a topic for further research. Certainly the intense political rivalry noticeable between the different press groupings in 1914-15 seems absent. Maybe it signals the move over that time period towards a more consensual society, the effects of the Depression, or a lessening of the ties to Britain. What is not different is the length of time it took for any decision to be made about who would be sent as official war correspondent. In World War I it took eight months from the outbreak of war until Ross was appointed. It took six and a half months for Hall to be appointed. There appeared to be no public expression of dismay at the delay in appointing him. The government was also dithering on whether to appoint a second correspondent or a photographer, and it continued to dither until mid-1941.

\section{Government decision-making concerning war correspondents}

Research in the national archives in Wellington does provide further information about what was occurring during this time within government circles. In the midst of ordering 16,000 pairs of boots and establishing the Papakura Army Camp, the Cabinet, in August 1939, appointed John Thomas Paul, a prominent socialist and journalist, as director of publicity, with Hall as his deputy (Censorship, 1939). The publicity positions were to remain inactive until the government imposed censorship and control of publicity (War Cabinet decisions Vol 1, 1939), which it did once war was declared in September. Prior to making an official decision to appoint a war correspondent in December 1939 the government was considering proposals for an official cine photographer, an official photographer, six official recording officers/historians and one official war correspondent (Staff - Official war correspondents- 
Middle East). The 1st echelon, consisting of 2nd NZEF Headquarters and a brigade group and totalling around 6500 men of all ranks, sailed in January to little public acknowledgement, compared with the fervency of the troop farewells in the previous war.

News of the departure of the troopships could not be published until released by the Director of Publicity. The release came last evening simultaneously with the announcement that the troops are now in Egypt. Only in Lyttelton, on the memorable afternoon, when troopships took aboard the Burnham men and steamed to sea with H.M.S. Leander as escort, was there a rousing farewell from the public. At Wellington there were no last-minute farewells and few spectators of an event which is now history. (Long voyage ends safely, 1940)

It is hard to understand why some of the photographers or newsmen did not accompany those troops to Egypt. In March 1940 Cabinet discussed the sending of a broadcasting unit overseas consisting of three men and a fully equipped truck. It took another two weeks before any discussion occurred of the need to send press correspondents to the front. It was not until March that Paul wrote to the Minister of Defence to say he had consulted with the New Zealand Journalists' Association about setting up a committee to select a correspondent. This was done and consisted of the president and secretary of the NZJA, A. A. Hardcastle and A. W. Pharazyn, Paul, and Oliver Duff, the founding editor of The Listener. After considering all the applications, six outstanding candidates were identified. They were H. D. (Doug) Brass, O. (Oliver) A Gillespie, J. H. (Bert) Hall, G. (Gerry) F Harcourt-Wybert and R. (Bob) T. Miller. The unanimous decision of the committee was that the position of official war correspondent should be offered to Miller (Staff-Official war correspondents-Middle East). When war was declared, 23-yearold Miller was a reporter on the staff of the Auckland Star. He was one of the first to enlist and was posted to the second divisional signallers with the rank of signalman and travelled with the 1st echelon. On arrival in Egypt, he became closely associated with the official news service of the 2nd NZEF (War correspondent—Second appointment, 1940).

Despite the recommendation of the selection committee, Cabinet approved Hall (42), previously the editor of The Dominion (1933-37), the Hawera Star and the Christchurch Sun. Hall was given the nod on April 15 with a second 
correspondent 'deferred in the meantime, to be brought up later for further consideration'(War Cabinet decisions Vol 3, 1940). Prior to Hall's editorships, he had also served in various positions on the Southland Times and the Press. According to Robyn Hyde, Hall was the youngest New Zealander to have had the control of a metropolitan daily, the Christchurch Sun, 'and splendidly he carried out his task' (Hyde, 1934, p. 194). He was also 'reserved, quiet, but always friendly' and 'never under any circumstances ill-tempered or unfair' and 'everyone...liked and trusted him' (p. 194). In 1938 he was the officer in charge of the New Zealand stand at the Empire Exhibition in Glasgow. He had a Diploma in Journalism and an MA, was married with two children, and before being made deputy director of publicity under Paul, was publicity manager and editor of New Zealand Railways Magazine (War correspondent, 1940). Two forms of correspondent now existed at the same time; one governmentappointed official correspondent, Hall, and one military sanctioned soldier/ correspondent, Miller.

Similarly to William Massey's government of 1914, the Labour government of Peter Fraser (who had largely taken over the reins of leadership since the illness of Michael Joseph Savage), seemed as equally reluctant to made decisions about how the war was to be reported to the New Zealand public. Despite discussing other possible coverage such as photographers and cinematographers, no decisions were made. A passive press certainly did not spur the 1939 government into action, as did the press of 1914-15. No reason was given why the appointment committee's decision in favour of Miller was overturned by Cabinet. The New Zealand public never learned which journalists had been considered, unlike in 1915 when the final four candidates were much discussed. It is clear government was keeping a tight hold on any publicity relating to correspondents. It became notorious later for its secretiveness around the war. But the question remains, why was there no debate in the newspapers? Why were there no editorials demanding information? Why were there no letters to the editor asking who was going to send back news of what the 2nd NZEF was up to? The silence is puzzling and will be examined in more detail in later research.

\section{Reaction to Bert Hall's appointment}

Unlike the reaction to Malcolm Ross's appointment as official war correspondent in 1915, Hall's appointment was greeted with acclaim. The Auckland Star 
said he was 'a journalist of wide experience and popular among members of the profession' (NZEF news, 1940). The Evening Post provided a potted biography ("War correspondent," 1940) and a photo of a thin-faced, bespectacled man (Mr J. H. Hall, MA ...., 1940). It recorded his farewell by the staff of the Prime Minister's Department, and his presentation of a 'pneumatic mattress and a propelling pencil suitably engraved' (Personal items, 1940). He was also to get a new portable typewriter.

It is clear from his farewell by his fellow journalists that Hall was held in high regard by them.

Mr A. A. Hardcastle, president of the New Zealand Journalists' Association, congratulated $\mathrm{Mr}$ Hall on his appointment and wished him all success in difficult and responsible work overseas and a speedy and safe return to New Zealand. It was because of their recognition of Mr Hall's capabilities as a newspaperman and of his breadth of character and impartiality that the whole weight of opinion among journalists supported the government in its selection of Mr Hall as the outstanding applicant, for the position. (High tributes-War correspondent with NZEF, 1940)

Hall was presented by his confrères with an inscribed gold watch. An old Christchurch newspaper colleague of Hall's, the Minister of Industries and Commerce, D. G. Sullivan, said he had met many newspaper people since the selection of Hall had been announced, 'and the opinion invariably expressed was that a good appointment had been made; from metropolitan newspapermen he had heard nothing but complimentary remarks about Hall's qualifications and the wisdom of the government in selecting him'(High tributes-War correspondent with NZEF, 1940). All that was left for Hall to do now was to sign the declaration acknowledging he had read the regulations for press representatives accompanying a force in the field overseas issued by the War Office in October 1939 and undertake to comply with all relevant regulations, rules and orders as required. This he did on April 24 after which he was gazetted as the official war correspondent to accompany the 2nd echelon (Second echelon, 1940). Hall was not to receive a military rate of pay as he was a permanent officer of the Railways Department. His salary was to be $£ 715$ per annum (Staff-Official war correspondentsMiddle East). At the beginning of the 1939 war it had been announced that war correspondents would not be granted commissions. They were issued 
with officer's uniform, minus badges of rank, and enjoyed all the privileges of officers but were not entitled to a salute (War news, 1940). The troopships sailed from Wellington on 2 May 1940 but instead of travelling to Egypt were diverted to Scotland, arriving there on June 16, for a stay of about seven months.

The 2nd echelon now had a correspondent but he was not in a war zone. All the 1st echelon in Egypt had was signalman Bob Miller occasionally acting as the journalist who wrote up the official 2nd NZEF news. A keen motorcyclist, he was a despatch rider in Egypt when he was not writing articles for the news service. Like Hall, Miller was well regarded by his fellow journalists, in Auckland at least. His personal popularity among his journalistic colleagues was such that they carried him shoulder high to the railway station the night he entrained for Trentham (War news, 1940). Like Hall, and unlike Malcolm Ross, Miller was a well-educated man, having been to university and gained a Diploma in Journalism.

Educated at the Auckland Grammar School and Auckland University College, he began newspaper work with the Auckland Star in 1935 as first cadet. Such was his ability that he won accelerated promotion, and made a name for himself by becoming a general reporter in his third year of journalism. Mr Miller has a flair for interviewing, and is a fine descriptive writer. (War news, 1940)

Table 1: Coverage from 2nd NZEF Official News Service in Egypt, 1940
\begin{tabular}{|l|c|c|}
\hline Paper & $\begin{array}{c}\text { 2nd NZEF official news service } \\
\text { No. of stories }\end{array}$ & $\begin{array}{c}\text { Days to publication } \\
\text { April-May 1940 }\end{array}$ \\
\hline Auckland Star & 6 & 28 \\
\hline Evening Post & 3 & 30 \\
\hline Bay of Plenty Beacon & 12 & 28 \\
\hline
\end{tabular}

Despite his obvious attributes, he was not an official correspondent. Astonishingly, he did suffer from the same handicap as Ross did in $1915 \ldots$ his 2nd NZEF despatches arrived very late. While Hall was sending back despatches from England within a day or two, Miller's were often weeks late, as Tables 1 and 2 show. New Zealanders were not being well served from Egypt.

Not only had there been no official war correspondent in Egypt with the 1st echelon since it had arrived in February 1940 but there had been no 


\begin{tabular}{|c|c|c|c|c|}
\hline Paper & $\begin{array}{c}\text { JH Hall } \\
\text { No. of stories }\end{array}$ & $\begin{array}{c}\text { Days of } \\
\text { publication }\end{array}$ & $\begin{array}{l}\text { 2nd NZEF } \\
\text { official news } \\
\text { service }\end{array}$ & $\begin{array}{l}\text { Days of } \\
\text { publication }\end{array}$ \\
\hline Auckland Star & 25 & $1-2$ & 10 & 22 \\
\hline Evening Post & 27 & $1-2$ & 7 & 17 \\
\hline $\begin{array}{l}\text { Bay of Plenty } \\
\text { Beacon }\end{array}$ & 10 & 31 & 8 & 34 \\
\hline
\end{tabular}

photographers or cinema unit. The radio unit did leave for Egypt with the 3rd Echelon but did not arrive there until September, 1940. Cabinet again discussed appointing an official photographer and cinematographer in June but any decision was delayed for further consultation (War Cabinet decisions $\mathrm{Vol} 4,1940$ ). Finally amid decisions to buy 25,000 web anklets from Canada and 500,000 yds of flannelette from India, Cabinet on October 25 agreed to appoint Miller as second official war correspondent with pay and allowances equivalent to a lieutenant as from October 1. Cabinet also approved a grant to purchase a camera and in light of Miller's journalistic services for the 2nd NZEF Official News, a grant of $£ 50$ (War Cabinet decisions Vol 5, 1940).

While General Bernard Freyberg, commander of the 2nd NZEF, approved of Miller's appointment as war correspondent and still photographer he told the Prime Minister, Peter Fraser, he also wanted a cinematograph operator and equipment to come out with the next lot of reinforcements. The Australians had a cinema unit and both 1 st and 2 nd contingents had official photographers who were also cinematographers (Staff - Official war correspondents-Middle East). Freyberg also wanted a public relations officer to co-ordinate all publicity and asked if he should find a suitable person or would Fraser send someone from New Zealand (New Zealand Forces - Special units-War correspondents). His requests went unanswered until the 2nd echelon, with Hall, finally reached Egypt in January 1941. Hall fell ill with pleurisy and then resigned to join the army and was appointed public relations officer with the rank of captain, leaving Miller as the only accredited war correspondent, with the 2nd NZEF about to take part in the battle for Greece. Freyberg recommended Gunner R (Bob) J. Gilmore of the anti-tank regiment as the replacement and it appears he may have taken up the position unofficially (Staff-Official war correspondents-Middle East). The government did not intend to appoint a second correspondent, Defence Minister Jones told the Evening Post. 
Not only that, Jones also poured cold water on the notion of appointing an official artist (Army appointment, 1941). However, an official photographer to the 2nd NZEF was under consideration, reported the Auckland Star (NZEF News, 1941) and Freyberg got his wish regarding the film unit. On January 27 Cabinet had approved such a unit and appointed Merv Elias and Ron McIntyre as operators (War Cabinet decisions Vol 7, 1941).

The United Press Association was so concerned about the lack of news, it considered appointing a war correspondent to the Middle East itself, but nothing came of it, although the Auckland papers agreed the association should send someone. They believed an 'association man' would have a freer hand than Miller, who they saw as a civil servant (Minutes of the board of directors, UPA, 1941). But it was the secretiveness surrounding the battle for Greece that finally prompted the Auckland Star to write a stinging editorial.

Reference has been made in these columns several times to the lack of official news of the doings of the 2nd NZEF and to the obviously unsatisfactory methods the government had adopted to handle the matter of publicity. There were two so-called war correspondents, then one was appointed to the fancy position of Public Relations Officer when the New Zealand Division was formed on arrival of the 2nd Echelon at Egypt. When it was announced that the New Zealanders had arrived in Greece it was naturally assumed that the war correspondent would be with them. This, however, does not seem to be the case. (News from the battle front, 1941)

Referring to 'flattering reference' being made to the Anzacs, the editorial asked why not one word had come from the New Zealand war correspondent.

There was a somewhat lengthy dispatch from the correspondent, datelined Cairo, and it seemed obvious from it that the correspondent is being kept at a distance of nearly 600 miles behind the lines, with the broad, rolling Mediterranean between him and the fighting sons of New Zealand. All the news the correspondent sent was what he had been told by men who had returned from Greece, but it was interesting to know that Greece in some parts looked like Taihape. (News from the battle front, 1941)

The editorial concluded that the 'silence of the Sphinx' characterised New Zealand's official publicity department, and 'mothers, fathers, wives, brothers 
and sisters of the boys from these shores fighting for the greatest cause on earth, are left with their anxious thoughts unassuaged, and a grave injustice to unsurpassed gallantry is perpetrated'. The Star was wrong about Miller, however. He did go to Greece, in particular the Mt Olympus front, and was among those evacuated to Crete. He claimed he was the only war correspondent to secure cine-camera pictures of German parachutists landing on the island (Biography of R. T. Miller, 1941). His predecessor Hall was not so lucky. He was captured at Corinth by the Germans in April and then spent the rest of the war as a prisoner in German stalags (prisoner of war camps) (Prisoner of war, 1941).

It was clear that the public of New Zealand was not well served, as the Auckland Star had continued to point out. For example, an editorial noted comments made in England by Brigadier L. M. Inglis concerning the operations in Crete which 'provided an illustration of the deficiencies of the news service which is maintained at the taxpayers' expense to furnish New Zealand with news of the NZEF' (News of the NZEF, 1941). The evacuation of Crete was announced on June 1, and Brigadier Inglis arrived in England on June 11.

There is also in Egypt an NZEF Official News Service, as well as an official war correspondent. Those who know the capacity of this correspondent can feel confident that if permitted he would endeavour to obtain, from Brigadier Inglis or from some other senior officer of the NZEF, just such a description of the campaign as the brigadier furnished in London; yet none was issued for publication in New Zealand. Why this should be so it is impossible at this distance from Egypt to explain; but it is beyond question that a statement such as that made by Brigadier Inglis in London could have been made by him or someone else in Egypt, and much earlier, and that the people in New Zealand were entitled to have it earlier.(News of the NZEF, 1941)

The 2nd NZEF official news service should be engaged in furnishing information daily concerning the welfare and activities of the troops who survived the Greece and Crete campaigns, said the editorial. 'Some other publicity is needed besides that of the casualty lists' (News of the NZEF, 1941).

It was not until after Peter Fraser's visit to the Middle East in May 1941 that a Public Relations Office was established to co-ordinate information and news for those back home. 
There were many matters to discuss, and the presence of the Prime Minister, keyed up as he was by the intensity of the war situation, helped to settle on the spot many things that might otherwise have dragged on for months. The long delay about war correspondents was ended on the spot, the Prime Minister remarking that they did not appear to have been handling it at all well in New Zealand, and authorising certain appointments at once. (Stevens, 1958)

The staff of the office included the public relations officer and official archivist (E. H. Halstead), an assistant archivist (E. H. McCormick), an artist (Peter Mclntyre), two war correspondents (Miller and W (Bill) S. Jordan), a photographer (Harold Paton), a broadcasting unit (Norman Johnston, Noel Palmer, Doug Laurenson) and a cinema unit (Ron McIntyre and Merv Elias) (Middle East, 1941). In the official history of the 2nd NZEF, under 'problems', Major-General W. G. Stevens commented:

We never knew the exact reasons which led to the outcome that all correspondents were military personnel paid by the government, and were not representatives of the New Zealand press; the discussions not to say controversy, between the government and the press, difficulties in selecting personnel, and basic suspicion in the Government of any outside publicity, caused absurd delays before any proper appointments were made. We were forced to make one or two interim appointments ourselves; and it may be said now that after a few correspondents had come out from New Zealand, later appointments came from competent newspapermen from the Expeditionary Force itself. (Stevens, 1958)

It had taken 22 months for a system of gathering and reporting the war news to be organised.

\section{Conclusion}

The New Zealand government was just as ill prepared in 1939 for the need to address the issue of official correspondents to cover the war as it had been in 1914. When war was declared on Germany on 3 September 1939 it still took until March the following year for an official war correspondent Bert Hall, to be chosen, and another two months before he departed with the 2nd Echelon of the 2nd NZEF. This was despite provision having been made in August for a director and deputy director of publicity under the Censorship and Publicity Emergency Regulations, who would presumably have 
been responsible for expediting the appointment of correspondents. The 1st Echelon had left in January 1940 for Egypt without either a correspondent or a photographer on board. New Zealanders had to rely on other nations' journalists for news although the 2nd NZEF did establish an official news service manned, as able, by an enlisted journalist, Signalman Bob Miller. But like the Gallipoli campaign of 1915, the news was delayed, taking at least a month, sometimes longer, to reach New Zealand. When the 2nd Echelon was diverted to the UK, reaching Scotland in June 1940, Hall's coverage thereafter of the New Zealand troops was very timely in comparison, often taking only a day or two to be published back home. But even the 3rd Echelon, which arrived in Egypt in September 1940, did not have an official correspondent in its complement, although it did have a three-man radio broadcasting unit.

It was another month before Bob Miller was finally appointed as the second official correspondent. Now the country had two journalists, well regarded by their confrères, to cover the actions of the New Zealand troops. This was not to last, however, because when Hall finally arrived in Egypt in January 1941 he promptly resigned to join the army and was appointed public relations officer; this at a time when the 2nd NZEF was about to embark on its first major engagement of the war, the battle for Greece. Dissatisfaction with coverage of that battle and then the retreat from Greece and subsequent evacuation from Crete finally saw the establishment in July 1941 of a Public Relations Office to oversee the work of war correspondents, photographers, artists, cinema and radio units and recording officers. It had taken nearly two years to see some sort of order created around press and broadcasting coverage of the 2nd NZEF's participation in the war. The blame for this must rest with both the government and the office of the publicity director, who dithered and delayed, seemingly unable to make decisions. It should also rest with the nation's press which, unlike in the previous war, remained largely silent on the need for the country to be represented by correspondents during the war. These are interim judgements, of course, further research will reveal more.

\section{Notes}

1. In World War I, the first lot of troops that were sent in convoy to Egypt were called the Main Body, with later additions called reinforcements. In World War II, the first three major corps of troops sent overseas were called echelons. 


\section{References}

Anderson, F., \& Trembath, R. (Eds.). (2011). Witnesses to war: The history of Australian conflict reporting. Melbourne: Melbourne University Press.

Appointment of war correspondent. (1915/02/27). The Observer, p. 5.

Army appointment. (1941/03/31). Evening Post, p. 4.

Association, N. Z. J. (nd). The New Zealand Journalists' Association 1912-1962. Wellington: New Zealand Journalists' Association.

Bell, F. H. D. (1915). Letter to PA chairman.

Biography of R T Miller (1941). (R20110062 ADQZ 18886 WAII1 291 / DA 406/6). Archives New Zealand, Wellington.

Censorship. (1939/09/02). Evening Post, p. 9.

Cox, G. S. (1936/11/24). By tram to the front, Auckland Star, p. 6.

Expeditionary force: Press correspondents. (1914). (Hansard, Vol. 169 July 31, 1914). Wellington: New Zealand Government.

High tributes-War correspondent with N.Z.E.F. (1940/05/01). Evening Post, p. 15. Hyde, R. (1934). Journalese (1st ed.). Auckland: National Printing Company.

Long voyage ends safely. (1940/02/13). Auckland Star, p. 5.

McDonald, L. (1998). Bylines: Memoirs of a war correspondent. Roseville: Kangaroo Press.

McGibbon, I. (Ed.). (2000). The Oxford companion to New Zealand military history. Auckland: Oxford University Press.

Middle East. (1941/07/04). Evening Post, p. 4.

Minutes of the board of directors, UPA. (1941, 1941/05/29). (MSY 6189). Alexander Turnbull Library, Wellington.

Mr J. H. Hall, MA (1940/04/16). Evening Post, p. 7.

NZEF news. (1940/04/15). Auckland Star, p. 8.

NZEF News. (1941/03/31). Auckland Star p. 4.

New Zealand Forces-Special units-War correspondents. (R18871710 ACIE 8798 EA1601/87/5/12 1 ). Archives New Zealand, Wellington.

News from the battle front. (1941/04/26). Auckland Star, p. 5.

News of the day. (1940/02/06). Auckland Star, p. 6.

News of the day-War correspondent candidates. (1940/04/06). Auckland Star, p. 8.

News of the NZEF (1941/06/28). Leading article, Auckland Star p. 6.

Oosterman, A. (2008). Malcolm Ross: From the peaks to the trenches. (Unpublished PhD Doctoral Thesis), AUT University, Auckland, New Zealand.

Oosterman, A. (2010). New Zealand war correspondence before 1915. Pacific Journalism Review, 16(1), 133-152.

Our war correspondent. (1915/09/18). New Zealand Truth, p. 7.

Personal items. (1940/04/26). Evening Post p. 11.

Prisoner of war. (1941/07/29). Evening Post, p. 9.

Purser, P. (2008/04/04). Sir Geoffrey Cox: A pioneer of broadcast news, he covered the Spanish Civil War and later founded ITV's News at Ten, Obituary, The Guardian. Radio unit. (1940/04/10). Evening Post, p. 11. 
Second echelon. (1940/05/13). Auckland Star p. 10.

Staff - Official war correspondents-Middle East. (R22438871 AAYS 8638 AD1 Box 1344 319/13/4 ). Archives New Zealand, Wellington.

Stevens, W. G. (1958). Problems of 2 NZEF The Official History of New Zealand in the Second World War 1939-1945 (pp. 39). In Wellington: Historical Publications Branch.

War Cabinet decisions Vol 1. (1939). (AAFD 809 Box 1 (1)). Archives New Zealand, Wellington.

War Cabinet decisions Vol 3. (1940). (AAFD 809 Box 2 (3)). Archives New Zealand, Wellington.

War Cabinet decisions Vol 4. (1940). (AAFD 809 Box 2 (4)). Archives New Zealand, Wellington.

War Cabinet decisions Vol 5. (1940). (AAFD 809 Box 3 (5)). Archives New Zealand, Wellington.

War Cabinet decisions Vol 7. (1941). (AFFD 809 Box 4 (7)). Archives New Zealand, Wellington.

War correspondent. (1940/04/15). Evening Post p. 9.

War correspondent-Expeditionary force. (1939, 1939/12/08). Auckland Star, p. 8.

War correspondent — Question of appointment. (1940, 1940/01/17). Auckland Star, p. 8.

War correspondent-Second appointment. (1940/10/26). Evening Post p. 10.

War correspondent Mr Malcolm Ross appointed. (1915/03/31). Evening Post, p. 7.

War correspondents. (1940/01/10). Evening Post, p. 7.

War correspondents. (1940/02/24). Auckland Star, p. 6.

War news. (1940/10/26). Auckland Star, p. 8.

Dr Allison Oosterman is a senior lecturer in journalism at Auckland University of Technology in New Zealand. Her current research field is New Zealand's World War II correspondents.

aoosterm@aut.ac.nz

204 PACIFIC JOURNALISM REVIEW 20(2) 2014 